\title{
Quality of Favorite Places in Community Residents in The Islamic Village of Kepaon, Pemogan, Denpasar
}

\author{
Gede Herry Widyatma ${ }^{1}$ \\ Program Study of Architecture, Faculty of Engineering, Udayana University \\ Faculty of Engineering, Udayana University \\ Denpasar, Bali \\ widyatma1976@gmail.com
}

\begin{abstract}
The existence of a favorite place is a public space that has an important role in the development of villages in urban areas. In the city of Denpasar there are many kampung-kampung (kampung-kampung: a community) that have many favorite places, where the existence of favorite places itself has quality with various facilities. This study aims to determine the quality of people's favorite places in the neighborhood. This study aims to determine the quality of people's favorite places in their neighborhood. The focus of the problem raised is places that are considered favorite by the people in their neighborhood and how the quality of physical object facilities, non-physical object facilities and infrastructure facilities at the favorite places. The research method used is a qualitative method, with a case study approach, the technique for collecting research data is through interview techniques, where the speakers come from people who live in Kepaon Islamic Kampung, Pemogan, Denpasar, asked to write on a piece of paper the places that people consider favorite according to their feelings, this writing technique aims to avoid the occurrence of the expression of feelings towards a favorite place between one resource person with another resource person. This research shows that there are many favorite places in the area of Kampung Islam, Kepaon, Pemogan, Denpasar, but favorite places that have quality with good facilities that are chosen by many people in their neighborhoods such as; Al-Muhajirin Kepaon Mosque, Sungai Taman Pancing Tukad Badung, Kertha Boga Market. The role of the community as well as the government is able to care for and maintain the quality of these favorite places, so that the community is guyub (guyub: close-knit interaction) to live in the area.
\end{abstract}

\section{Index Terms - favorite places, community, neighborhood}

\section{INTRODUCTION}

Place is a space that is given meaning by its users [1][2]. Place is defined as a space that has cultural significance and social processes. Space changes into a place, when there are social ties, feelings and emotions of users [2][3].

Various disciplines have tried to study the relationships formed between humans and places, including: human geography, human behavior and the environment, sociology, and environmental psychology [1][4]. One common response about a person's inner attachment to a place is visiting favorite places, which can create a response to a person about feelings of comfort, intimacy, and pleasure to that place. Ideal and preferred places associated with favorite places [5][6].
Denpasar City is a city on the island of Bali and at the same time the capital of Bali Province, Indonesia, according to BPS data Denpasar has a population growth rate of approximately $4 \%$ a year, and is a city that has a very heterogeneous population so that there are many communities formed one of them is in the form of "villages", such as the one in the Pekraman Pemogan Village area which is named Banjar Dinas Kampung Islam Kepaon Pemogan.

Some of the residents of the Kepaon Pemogan Islamic Village Denpasar, are descendants of soldiers from Raden Mas Cokro Panolo Bangsawan Bugis who married the daughter of the King of Pemecutan Kingdom named Anak Agung Mas Dewi. After marrying as a Mualaf with the name "Siti Kadijah", Siti Kadijah was then killed by local residents, as many as forty (40) remaining soldiers of Raden 
Mas Cokro Panolo moved to the Kepaon area and settled in the area [7]. This is where the beginning of the formation of a village located in the Kepaon Traditional Village.

Kampung Islam Kepaon, Pemogan, Denpasar is an area that has its own uniqueness, namely residents who have lived in this area for a long time, it is very difficult to move out of the Kepaon Pemogan Islamic Village area, this is due to the sense of inner attachment of the community to the environment in which they live, wrong One factor of people's inner attachment to their environment is that there are many favorite places. Favorite places are formed due to a process of feeling happy, comfortable, and familiar with someone in a place, so that people often visit these places. .

One of the factors of feeling happy, comfortable, and familiar with someone visiting a favorite place is the presence of good quality facilities such as physical object facilities, non-physical object facilities and infrastructure facilities found in these favorite places. This is an interesting phenomenon to study regarding the places that are considered favorite and the quality of the facilities for favorite places in the Kepaon Islamic Village Area, Pemogan, Denpasar.

\section{METHOD}

The qualitative research method [8] was chosen in this study because it is very difficult to know someone's feelings about a place, so direct observation in the field is needed to determine the natural environment (natural setting). And the approach chosen is a case study approach [9], this is because this research examines the behavior of a group or community in the Kepaon Islamic Village, Pemogan, Denpasar and the research area has a narrow (micro) area.

There are several guidelines using case studies in this research, namely: (1) Planning to answer the problem formulation on the problems of places that are considered favorite and the feeling of comfort, pleasure and familiarity of the people in the research area regarding these favorite places; (2) Finding data sources by contacting influential people in the research area; (3) data processing by coding every interview or writing; (4) negotiating the results of the study with theory, (5) formulating conclusions on the results of the discussion.

To obtain data, a technique was carried out by inviting residents of Kepaon Islamic Village, Pemogan, Denpasar to find out people's favorite places in the neighborhood where they live according to as well as places they are frequently visited. After that, make observations on the quality of the facilities for the favorite places of the community, the facilities in question are physical object facilities, nonphysical object facilities, and finally infrastructure facilities.

Data mining is carried out in two stages, the first stage is the preparation stage, through performance base selection [10], this is useful for overcoming barriers to language, age, and educational background, length of stay of residents in the area, and Finally, the selected sources are those who live in each location in the research area of the Kepaon Pemogan Islamic Village, Denpasar (not grouped in one neighborhood).

This stage involved the chairman of the Al-Muhajirin Foundation organization, Kepaon Pemogan Islamic Village, Mr. Haji Ishak, along with the management staff of the foundation's organization and the sub-department of the Office of Mr. Muhamad Asmara, to invite the public to attend the interview, potential resource persons themselves were determined as follows: (1 ) Age between 18 and 60 years, (2) Have a Resident Identity Card and have been living in this area for a long time, (3) The lowest education is high school or equivalent, (4) and does not live in one neighborhood (one place)

Kepaon Islamic Village, Pemogan, Denpasar consists of 5 total tempek. Tempek one is residents who live in the area of Gang Muhajirin one to Gang Muhajirin lima, tempek two residents who live around the Gang Soleh area, and tempek three residents who live around the Jalan Taman Pancing area, then proceed with tempek four residents who live around the area The graves of "Abah" to Gang Soka, and lastly, five residents who live far outside the Kepaon Pemogan Islamic Village area but are still domiciled in this area to be more clearly defined in Figure 1 below.

The number of people invited to be interviewees in one tempek with another tempek has different numbers of sources, this is determined by $\mathrm{Mr}$ Kelian Dinas and $\mathrm{Mr}$ Chairman of the Al-Muhajirin Foundation. The reason is because each tempek has a different number of residents, the first tempek consists of five sources, the second tempek has four sources, the third tempek has four sources, the fourth tempek has three sources, and finally the fifth tempek has two sources, so a total of seventeen speakers.

For the next stage used is the interview method by writing (Morissan, 2012), by asking participants to write down their favorite places and feelings that exist in these favorite places. While the place to hold the meeting is located in the area of Madrasah Aaliyah Yayasan Al-Muhajirin, the Islamic Village of Kepaon Pemogan Denpasar, when the implementation was held on Sunday, May 32019.

\section{QUALITY FAVORITE PLACE IN THE NEIGHBORHOOD}

\section{A. Quality}

The definition of quality according to Goetch and Davis [11] is a dynamic condition related to products, services, people, processes and environments that meet or exceed expectations, while the definition according to Deming [12] about quality is that quality must meet customer needs now and in the future, and finally Crosby's [13] definition of quality is conformity to needs which includes availability, delivery, reliability, maintainability, and cost effectiveness. The term quality is inseparable from quality management, one of which is learning about facilities [11].

Facilities are generally defined in 2 different main senses. (1) Facilities defined as part of infrastructure. (2) Facilities 
are defined as things that are necessary for life, which can be in the form of physical objects or non-physical objects. Examples of facilities can be seen: (1) Examples of infrastructure facilities include: air conditioning, elevators, lighting, electrical installations, and others. (2) Examples of physical object facilities include sports stadium facilities and others. (3) Examples of non-physical object facilities include catering services [14][3].

\section{B. Favorite Place}

The living environment is a residential environment with the main function of being a place to live equipped with environmental infrastructure and facilities, a place to work that provides services and job opportunities that can support life and livelihoods [15]. Residential environment facilities are supporting facilities that function for the organization and development of economic, social and cultural life [16]. Examples of residential facilities are shopping center facilities, public services, education and health, places of worship, recreation and sports, parks, cemeteries [17].

\section{Living environment}

The living environment is a residential environment with the main function of being a place to live equipped with environmental infrastructure and facilities, a place to work that provides services and job opportunities that can support life and livelihoods [15]. Residential environment facilities are supporting facilities that function for the organization and development of economic, social and cultural life [16]. Examples of residential facilities are shopping center facilities, public services, education and health, places of worship, recreation and sports, parks, cemeteries [17].

\section{DATA AND ANALYSIS}

\section{A. Overview of the research locus}

Kepaon Pemogan Islamic Village is located in Kepaon Traditional Village, Pemogan, Denpasar, more precisely $8^{\circ}$ 41 '44.65 "South latitude, $115^{\circ} 11^{\prime}$ '48.76" North latitude 12 m elevation $1.15 \mathrm{~km}$ eye level (Google Earth Pro accessed November 6, 2018 ). The boundaries of the Banjar Service area of Kepaon Pemogan Islamic Village are the North Boundary: Banjar Adat Gunung and Banjar Adat Kesuma Sari, East Boundary: Pesawahan, West Boundary: bounded by the Gelogor Adat Banjar, and finally the Southern Boundary: Banjar Adat Jaba Tengah, Banjar Adat Kajeng. For more details, it can be seen in Figure 1.

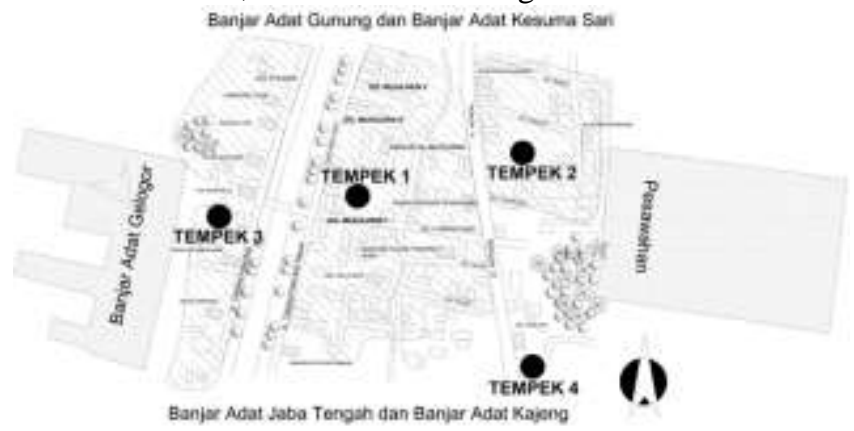

Fig. 1. Boundary Banjar Department of the Kepaon Pemogan Islamic Village Denpasar

Source: processed from Google Earth Pro accessed on 6 November 2018

\section{B. Analysis of Favorite Places in Kepaon Pemogan} Islamic Village Denpasar

There are 11 types of favorite places according to the feeling of pleasure, comfort, and familiarity of the Banjar people of the Kepaon Pemogan Denpasar Islamic Village Service, namely; Al-Muhajirin Mosque, Al-Muhajirin Kepaon Foundation, Raudhaftul Aftal Madrasah, AlMuhajirin Kepaon Foundation, Kindergarten level, Sungai Taman Pancing Tukad Badung, Madrasah Ibtidaiyah, AlMuhajirin Foundation School of education at Elementary School / SD level, and others, which can then be seen in table 1 below.

The favorite places chosen by the speakers are also seen in places that are out of concept (idiosyncratic) such as; The front porch of the residence, which is located along Jalan Taman Pancing west and Jalan Taman Pancing in the east and the Kepaon Public Cemetery, known as the place of the Abah Tomb, is also a favorite place.

TABLE I

THE NUMBERS OF THE TOTAL POPULATION.

\begin{tabular}{|c|c|c|c|}
\hline No & Favorite Place & Address & Reviewer \\
\hline 1. & Mesjid Al-Muhajirin & $\begin{array}{l}\text { Jalan Raya } \\
\text { Pemogan }\end{array}$ & 16 \\
\hline 2. & Pasar Kertha Boga Pemogan & $\begin{array}{l}\text { Jalan Pulau } \\
\text { Bungin }\end{array}$ & 10 \\
\hline 3. & Sungai Tukad Badung & & 9 \\
\hline 4. & $\begin{array}{l}\text { Madrasah Raudhaftul Aftal } \\
\text { (M.RA) Yayasan Al- } \\
\text { Muhajirin, Kepaon (Sekolah } \\
\text { setingkat Sekolah Taman } \\
\text { Kanak-kanak) }\end{array}$ & $\begin{array}{l}\text { Jalan } \\
\text { Taman } \\
\text { Pancing } \\
\text { No. } 12\end{array}$ & 8 \\
\hline 5. & \begin{tabular}{llr} 
Madrasah & \multicolumn{2}{c}{ Ibtidaiyah (M.I) } \\
Yayasan Al- & Muhajirin, \\
Kepaon (Sekolah setingkat & Sekolah Dasar)
\end{tabular} & $\begin{array}{l}\text { Jalan Raya } \\
\text { Pemogan }\end{array}$ & 8 \\
\hline 6. & Sawah & $\begin{array}{l}\text { Kampung } \\
\text { Islam, } \\
\text { Kepaon, } \\
\text { Pemogan }\end{array}$ & 7 \\
\hline 7. & Ladang dan Kebun & $\begin{array}{l}\text { Sebelah } \\
\text { barat dan } \\
\text { timur } \\
\text { Kampung } \\
\text { Islam, } \\
\text { Kepaon, } \\
\text { Pemogan }\end{array}$ & 6 \\
\hline $\begin{array}{l}8 . \\
9 .\end{array}$ & $\begin{array}{l}\text { Serambi depan rumah tinggal } \\
\text { Madrasah Tsanawiyah (M.Ts) }\end{array}$ & & 5 \\
\hline & $\begin{array}{l}\text { Yayasan Al-Muhajirin, } \\
\text { Kepaon (Sekolah setingkat } \\
\text { Sekolah Menengah } \\
\text { Pertama/SMP) }\end{array}$ & $\begin{array}{l}\text { Jalan } \\
\text { Taman } \\
\text { Pancing } \\
\text { Barat No. } \\
13\end{array}$ & 3 \\
\hline 9. & $\begin{array}{l}\text { Tempat makam Kampung } \\
\text { Islam Kepaon }\end{array}$ & $\begin{array}{l}\text { Jalan raya } \\
\text { Pemogan }\end{array}$ & 2 \\
\hline 11. & $\begin{array}{l}\text { Madrasah Aaliyah (M.A) } \\
\text { Yayasan Al- Muhajirin, } \\
\text { kepaon (Sekolah setingkat } \\
\text { Sekolah Menengah Atas/SMA) }\end{array}$ & $\begin{array}{l}\text { Jalan } \\
\text { Taman } \\
\text { Pancing } \\
\text { Barat No. } \\
15 \\
\text { JUMLAH }\end{array}$ & 75 \\
\hline
\end{tabular}


The most favorite place according to the feelings of the people of Kampung Islam Kepaon, Pemogan, Denpasar such as the most comfortable feeling, the most intimate feeling, and the most happy feeling is (1) Masjid AlMuhajirin Kepaon, Pemogan, with a percentage of $100 \%$ which is located in the Banjar area of the Kepaon Islamic Village Service, Pemogan, Denpasar.

Other locations for the favorite places of choice for residents in the neighborhood in the Kepaon Islamic Village Area, Pemogan, Denpasar are (2) Pasar Kertha Boga, Pekraman Pemogan Village, which is located on Jalan Pulau Bungin, the percentage is 75\%, Pemogan and (3) Taman Pancing Tukad Badung river, the river that crosses the area of Kepaon Islamic Village, Pemogan, Denpasar, the percentage is $70 \%$. To be clear, it can be seen in Figure 2 below.

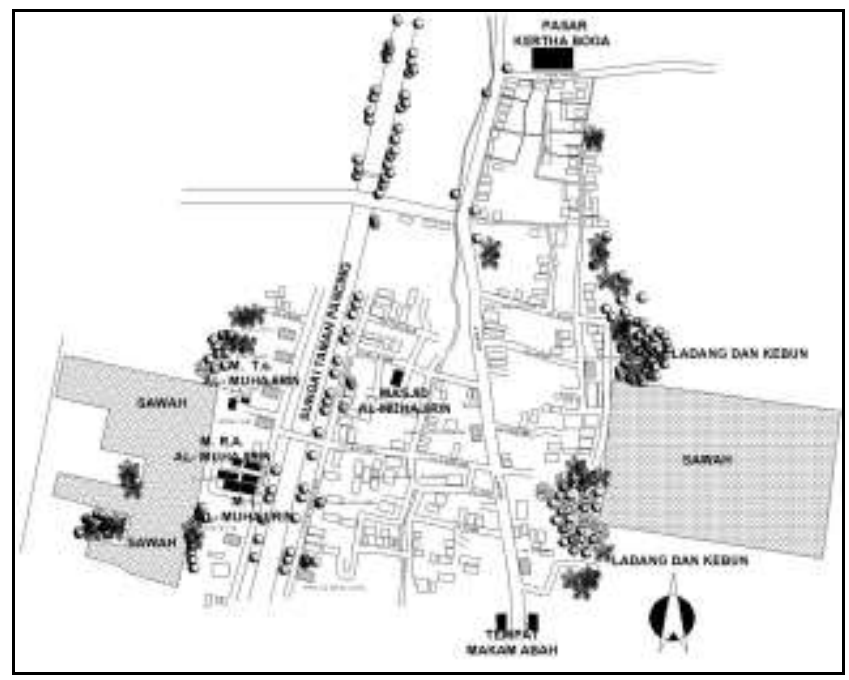

Fig. 2. Tempat-tempat favorit di Kampung Islam Kepaon Pemogan Denpasar

Source: processed from Google Earth Pro accessed on 6 November 2018

In table 1, there are the locations of favorite places and the number of reasons for choosing a favorite place in Kepaon Islamic Village, Pemogan, Denpasar. After that the research was continued by analyzing the reasons for feeling happy, comfortable, and familiar with the community for choosing this favorite place.

The reasons for these expressions are also written on a piece of paper, then the expressions of the community through writing in one-by-one coding are done in order to make it easier to analyze what the community means and can classify the direction of feelings, whether feeling happy, feeling familiar, and feeling comfortable.

The reasons for the people of Kepaon Islamic Village, Pemogan, Denpasar that were put forward were the feeling of being comfortable, familiar, and happy with the place. This feeling is the deepest expression of society, why they choose these favorite places. Details of the reasons for choosing this can be seen in Figure 3 below.

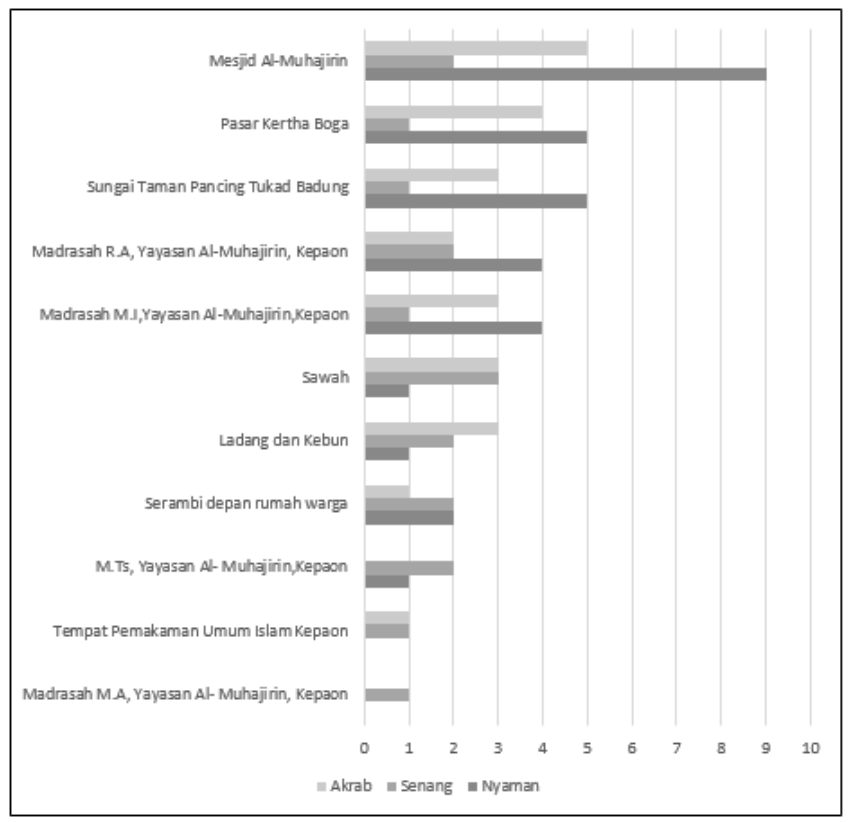

Fig. 2. Analysis of Feelings of the Community's Favorite Places in Kepaon Islamic Village, Pemogan, Denpasar.

From the description of the feelings of the community members towards their favorite places, almost $50 \%$ of the community members stated that their attachment to their favorite places was caused by the feeling of "comfortable" in these favorite places. Meanwhile, 30\% of residents' feelings towards their favorite places are caused by feeling "familiar" and the remaining $20 \%$ are feelings of community members due to feelings of "happy".

The domination of the "comfortable" feeling of the residents of Kepaon Islamic Village, Pemogan, Denpasar, in choosing their favorite places, of course one of them is due to the quality factor. The quality factor itself is influenced by the availability of facilities provided by these favorite places. The facilities for these favorite places can be described in the form of: (1) physical facilities, (2) nonphysical facilities, (3) infrastructure facilities.

These facilities can be seen in the favorite place of Masjid Al-Muhajirin Kepaon, Pemogan, Denpasar, which is in the first place for the residents' choice as the favorite place for local residents, then Kertha Boga Market, Pekraman Pemogan Village, and as the third choice for the Tukad Badung Fishing Park River.

\section{QUALITY FACILITIES FAVORITE PLACES}

\section{A. Overview of the research locus}

Masjid Al Muhajirin is one of the oldest mosques in Bali, located on Jalan Raya Pemogan, Al Muhajirin alley with zip code 80221, has an area of $40 \mathrm{M} \times 22 \mathrm{M}$, since its establishment until now it has undergone three renovations, namely in 1963 when the mosque was still The first floor is very simple, where the followers are still soldiers from Raden Mas Cokro Pranolo who have been in the area from generation to generation about 40 people, the mosque is still called Mesjid Al-Jammih. 
Then in 1976 the mosque was overhauled again because the immigrant community who lived in the Banjar Dinas of the Kepaon Pemogan Islamic Village, grew in followers, and through their own self-help they raised assistance to renovate the mosque. Using the services of an architect named Haji Maman Supratman, the mosque was made on the second floor using a mihrab in the shape of a niche on the wall and functions as a marker for the direction of the Qibla, where the first floor is for men to pray while the second floor is for women.

In 2014, the mosque was restored with the self-help of the people of Kepaon Pemogan Islamic Village and people who are Muslim outside the area who participated in praying at the Al-Muhajirin Mosque. For the quality of the facilities held at the Al-Muhajirin Mosque can be seen in table 2 below:

TABLE II

THE NUMBERS OF THE TOTAL POPULATION IN BADUNG REGENCY IN 2014

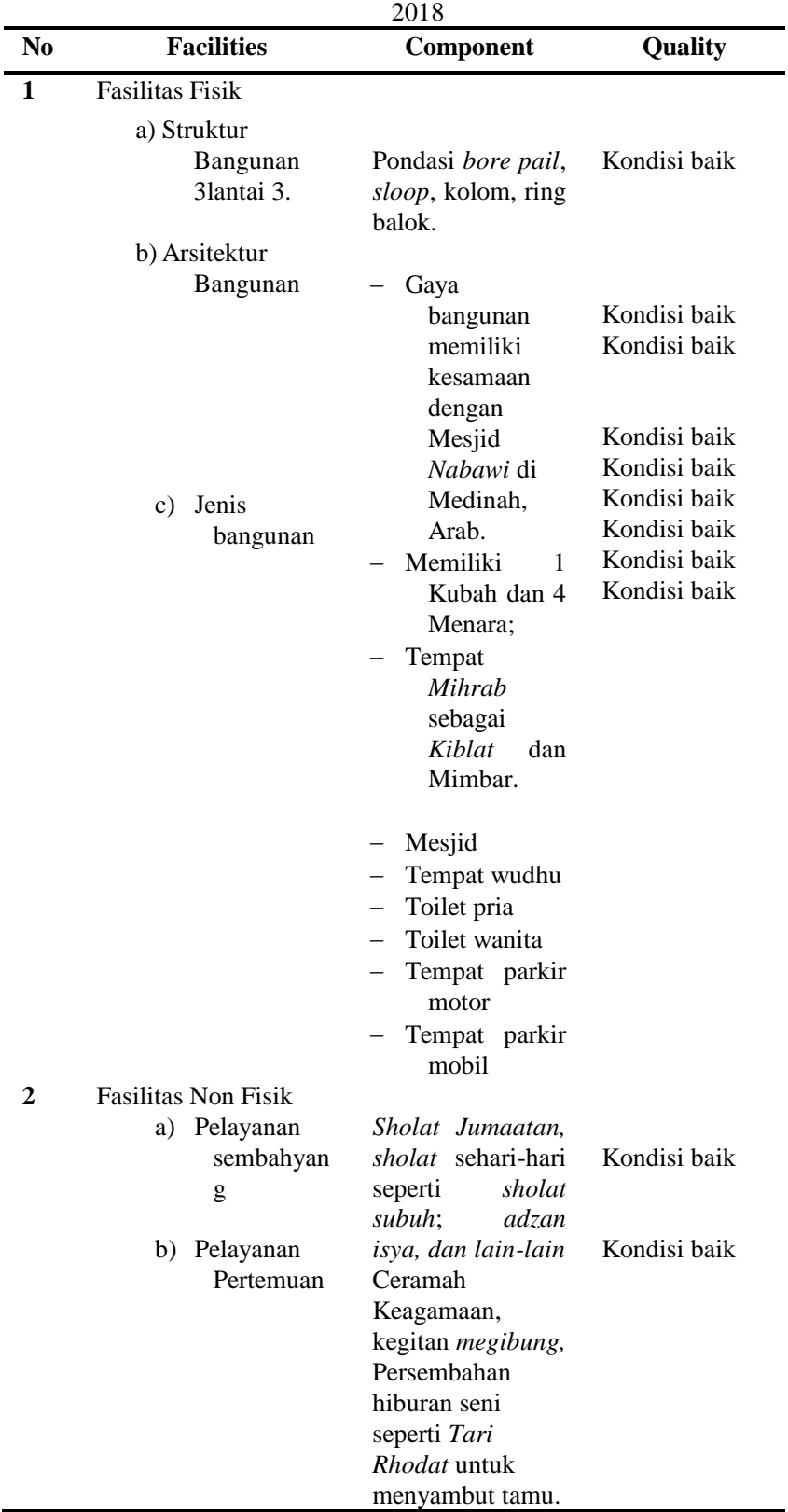

\begin{tabular}{cclrr}
\hline $3 \quad \begin{array}{c}\text { Fasilitas Infrastruktur } \\
\text { a) Instalasi }\end{array}$ listrik & Lampu, kabel, & Kondisi baik \\
b) Instalasi & kontak. $\quad$ stop & Kondisi baik \\
$\quad$ sanitasi & Kran air, $\quad$ Kondisi baik \\
c) perlengkapan & washtafel, pipa. & \\
& Kipas angin, AC \\
& portable. & \\
& Pengeras suara \\
& (sound system), \\
& TV LCD. \\
\hline
\end{tabular}

\section{B. Kertha market has pemogan pekraman village}

According to the statement of the Head of Pemogan Traditional Village, there are two markets, namely Kertha Boga Market and Windhu Catering Market, while for research, the favorite place in the market is the Kertha Boga Market, Pekraman Village, Pemogandi, Pemogan Village. Is a village market in Banjar Pemogan Kaja which is shaded by two pekraman villages, namely Pekraman Kepaon Village and Banjar Dinas Kampung Islam Kepaon, Pemogan, Denpasar.

The location of the Pemogan Traditional Village Kertha Boga Market is located on Jalan Bungin Island, for more details it can be seen in Figure 2 below. The Kertha Boga Market in Pemogan Traditional Village has experienced two market revitalizations, first the market was revitalized in 1994, then continued with the second revitalization in 2004, with quality facilities such as physical object facilities, nonphysical object facilities, and infrastructure facilities found in the market in table 3 below.

TABLE III

\begin{tabular}{|c|c|c|c|}
\hline $\mathbf{N}$ & Facilities & Component & $\overline{\text { Quality }}$ \\
\hline 1 & 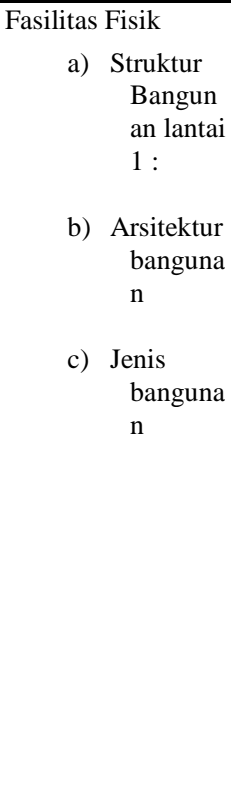 & $\begin{array}{l}\text { Pondasi menerus batu } \\
\text { kali, sloop, kolom, ring } \\
\text { balok. } \\
\text { Stil Bali pada kolom } \\
\text { bangunan } \\
\text { - Bangunan LPD } \\
\text { - Bangunan Serbaguna } \\
7 \text { Buah kantor } \\
\text { - Bangunan puan } 119 \\
\text { pengelola 1 buah } \\
\text { - Pedagang los } \\
\text { buah } 50 \\
\text { - Pedagang kios } \\
\text { buah } \\
\text { - Tempat Sampah } \\
\text { - Toilet Pria } \\
\text { - Toilet wanita } \\
\text { - Parkir Mobil } \\
\text { - Parkir motor } \\
\text { - Pos jaga }\end{array}$ & $\begin{array}{l}\text { Kondisi baik } \\
\text { Kondisi baik } \\
\text { Kondisi baik } \\
\text { Kondisi baik } \\
\text { Kondisi baik } \\
\text { Kondisi baik } \\
\text { Kondisi baik } \\
\text { Kondisi baik } \\
\text { Kondisi baik } \\
\text { Kondisi baik } \\
\text { Kondisi baik } \\
\text { Kondisi baik } \\
\text { Kondisi baik }\end{array}$ \\
\hline 2 & $\begin{array}{l}\text { Fasilitas Non fisik } \\
\begin{array}{l}\text { a) Pelayanan } \\
\text { pembeli } \\
\text { an }\end{array}\end{array}$ & $\begin{array}{l}\text { - Jasa membawa } \\
\text { barang belanjaan; } \\
\text { - Jasa untuk mengatur } \\
\text { parkir kendaraan; } \\
\text { - Pelayanan pembelian }\end{array}$ & $\begin{array}{l}\text { Kondisi baik } \\
\text { Kondisi baik } \\
\text { Kondisi baik }\end{array}$ \\
\hline
\end{tabular}




\begin{tabular}{ccccc}
\hline \multicolumn{4}{c}{ terhadap semua } \\
kebutuhan rumah \\
tangga. & & \\
& & \multicolumn{4}{c}{ Fasilitas } \\
Infrastruktur & Lampu, kabel, stop & Kondisi baik \\
a) & Instalasi & kontak, saklar. & Kondisi baik \\
& listrik & Kran air, Washtafel, & \\
& b) & Instalasi \\
& sanitasi & pipa. & Kondisi baik \\
& c) & Pengeras suara & \\
& pangka & (sound system), & \\
& & kipas angin. & \\
\hline
\end{tabular}

\section{CONCLUSION}

The quality of favorite places in the Kepaon Pemogan Islamic Village Area, such as the Kepaon Al-Muhajirin Mosque, Kepaon Islamic Village, Kertha Boga Market, Pekraman Pemogan Village, Sungai Taman Pancing Tukad Badung, makes community members visit these favorite places. With the better the quality of the facilities for these favorite places, of course, it will increase the feeling of comfort, pleasure, and familiarity of the community members to frequently visit their favorite places in the research area.

\section{REFERENCES}

[1] Altman, I. \& Low,S.M. (1992). Place Attachment, Human behaviour, and environment: Advances and in theory and research. In: New York: Plenum Press.

[2] Stedman.R.C. (2003). Sense of Place and Forest Science: Toward a Program of Quantitative research. Forest science, Vol.49, pp. 822829.

[3] Prohensky, H.M., Fabian, A.K., \& Kominoff,R. (1983). Place identity: Physical World Socialization of Self. Journal of Environmental Physicolgy, Vol.3, pp. 57-83.

[4] Riley, R.B. (1992). Attachment of Ordinary Landscape, In Place Attachment. Vol. 13-53, Springer

[5] SRT.(2009). Fasility Management. Information Booklet March 2009. Sport and Recreation Tasmania

[6] Wilkie, R., \& Wilkie, J. (1980). Environmental perception and migration behavior: A case study in rural Argentina. Cambridge, MA: Schenkman.

[7] Silado, R. (2008). Tradisi "Ngejot " jelang Idul Ftri di Bali. Bali post

[8] Maleong, R. J. (2007). Metodologi Penelitian Kualitatif. Bandung.

[9] Rahardjo, M. (2017). Studi kasus dalam penelitian kualitatif: konsep dan prosedurnya.

[10] Huck, S. W., Cormier, W. H., \& Bounds, W. G. (1974). Reading statistics and research: Harper \& Row New York.

[11] Goetsch, D.L., \& Davis, S. (1995). Implemating to Total Quality. New Jersey: Prentice Hall International, Inc.

[12] Ariani, D. W. (2003). Manajemen Kualitas Pendekatan Sisi Kualitatif. Penerbit Ghalia Indonesia, Jakarta.

[13] Crosby,P.B.(1979). Quality is free. New York: Mc-Grow Hilal

[14] Soemitro, R.A.A. \& Suprayitno, H. (2018). Optimasi Kasus Pengaturan Kombinasi Pemuatan Paket n Paket barang ke m Kotak Angkut. Jurnal Managemen Aset Infrastruktur \& Fasilitas, Vol.2, No.1, Maret 2018, pp.11-21

[15] Keman, S. (2005). Kesehatan perumahan dan lingkungan pemukiman. Jurnal Kesehatan Lingkungan, Vol 2, No.1.

[16] Krieger, J., \& Higgins, D. L. (2002). Housing and health: time again for public health action. American journal of public health, Vol. 92, No.5, pp. 758-768.

[17] Pandapotan, L. (1985). Perumahan Sehat, Pusat Pendidikan Tenaga Kesehatan 